\title{
Ex situ conservation of rare and endangered species in mushroom culture collections of Ukraine
}

\author{
Nina A. BISKO ${ }^{1}$, Maryna M. SUKHOMLYN² ${ }^{2}$ Oksana B. MYKCHAYLOVA ${ }^{1}$, Margarita L. LOMBERG ${ }^{1}$, \\ Nadiya V. TSVYD ${ }^{2}$, Yuriy V. PETRICHUK ${ }^{3}$, Galeb A. AL-MAALI ${ }^{1}$, Nadiya Yu. MYTROPOLSKA ${ }^{1}$ \\ ${ }^{1}$ M.G. Kholodny Institute of Botany, National Academy of Sciences of Ukraine \\ 2 Tereshchenkivska Str., Kyiv 01004, Ukraine \\ ${ }^{2}$ Educational and Scientific Centre "Institute of Biology and Medicine", Taras Shevchenko National University of Kyiv \\ 2 Hlushkova Avenue, Kyiv 03127, Ukraine \\ ${ }^{3}$ Hutsulshchyna National Nature Park \\ 84 Druzhby Str., Kosiv 78600, Ivano-Frankivsk Region, Ukraine
}

Bisko N.A., Sukhomlyn M.M., Mykchaylova O.B., Lomberg M.L., Tsvyd N.V., Petrichuk Yu.V., Al-Maali G.A., Mytropolska N.Yu. Ex situ conservation of rare and endangered species in mushroom culture collections of Ukraine. Ukr. Bot. J., 2018, 75(4): 338-347.

Abstract. Biodiversity loss, degradation of ecosystems and other global concerns emphasize urgent issues in nature conservation. Fungi as an important component of biodiversity need to be protected as much as other living organisms. In the article, two basic strategies in conservation are outlined and recent advances in fungal conservation, both in situ and ex situ, are considered. The key role of mushroom culture collections for ex situ fungal conservation is highlighted. Conservation of species diversity and genetic resources in culture collections provides the essential basis for biotechnological potential. The largest collections of fungi registered in the World Data Center for Microorganisms (WDCM), a unique global network for ex situ preservation of fungal and microbial diversity, are mentioned. Of the existing culture collections of fungi in Ukraine, the IBK and FCKU mushroom culture collections are characterized. A list of the species maintained in the IBK and FCKU collections, evaluated in the European countries against the IUCN criteria and categories and available at the European Council for Conservation of Fungi (ECCF) website as the preliminary European Red List of endangered macrofungi, is provided. A special attention paid in the IBK and FCKU collections to cultures of rare species of fungi, particularly of those listed in the Red Data Book of Ukraine, as well as the opportunity of the reintroduction into natural habitats are briefly discussed. Some examples of other rare species of fungi from these collections, potential candidates for national red-listing, are presented.

Keywords: conservation, culture collection, fungi, IUCN, Red List

Conservation of biological diversity is one of the key concerns of the present day. The Convention on Biological Diversity covers biodiversity at various levels from species to ecosystems and genetic resources. Fungi are known to be an important component of biodiversity at all these levels. Nonetheless, until the recent past fungi were rarely considered in conservation issues compared to plants or animals and were often overlooked in international biodiversity agreements. However, during the last two decades awareness of fungal conservation has noticeably raised.

The European Council for Conservation of Fungi (ECCF) founded in 1985 was the world's first organization to promote fungal conservation in Europe both on continental and national levels. Over about (c) N.A. BISKO, M.M. SUKHOMLYN, O.B. MYKCHAYLOVA, M.L. LOMBERG, N.V. TSVYD, Yu.V. PETRICHUK, G.A. AL-MAALI, N.Yu. MYTROPOLSKA, 2018 a 30-year period, the ECCF members have made considerable contribution to fungal conservation, advanced general awareness of endangered species of fungi and their habitats. As a conservation wing of European Mycological Association (EMA) since 2003, the ECCF enhanced mycological infrastructure within Europe through a network of experts dedicated to conservation of fungi. By 2010, mycologists in 33 European countries have conducted Red List assessments of fungi which resulted in 5500 species nationally red-listed (Dahlberg et al., 2010). A shortlist of about 1700 species relevant for Red List evaluation at the European level is currently available at the ECCF website (http://www.eccf.eu/activitiesen.ehtml). A great advantage of the ECCF activities was that applying the IUCN (International Union for Conservation of Nature) categories and criteria for 
the assessment whenever possible was encouraged. As a result, recently produced national Red Lists of fungi in many European countries at least partly meet the IUCN criteria. Moreover, red-listing efforts stimulate research initiatives on fungal distribution, population structure and dynamics, as well as provide necessary data for conservation decisions and actions (Dahlberg, Mueller, 2011).

Simultaneously with growing awareness of the importance of protecting fungi in natural habitats, or in situ conservation, there has been a greater understanding of the complementary strategy, ex situ conservation. Increasing loss of biodiversity, continued depletion of natural resources, on-going concerns over climate change and biosecurity issues highlight the value of culture collections of fungi and microorganisms as genetic resources.

The worldwide importance of culture collections was originally recognized at the First Conference on Culture Collections held in Ottawa, Canada, in 1962, attended by representatives from 28 countries. In 1970, the World Federation for Culture Collections (WFCC) was established; subsequently, the World Data Center for Microorganisms (WDCM) was founded as the WFCC data center. The WDCM has gradually developed into an extensive global network of microorganism resource centers. By September 2017, according to the WDCM database management system, Culture Collections Information Worldwide (CCINFO), 728 culture collections from 72 countries have been registered which maintain over 2.5 million of microorganisms cultures, including 806408 cultures of fungi (http:// www.wfcc.info/ccinfo/).

The growing demands on culture collections for authenticated, reliable biomaterial promote higher quality standards of scientific services provided for the development of biotechnology. Recently, the Organisation for Economic Co-operation and Development (OECD) has recognized the global value of culture collections as a significant element in the development of a knowledge-based bioeconomy (www. oecd.org). Thus conservation of genetic resources and species diversity provides the essential basis for biotechnological potential.

According to WDCM most recent data, the largest collections of fungi by number of cultures are registered in the Netherlands (Centraalbureau voor Schimmelcultures, CBS-KNAW) and the USA (Agricultural Research Service Culture Collection, NRRL; American Type Culture Collection, ATCC). These collections store each from over 40 to 60 thousand strains of fungi of various taxonomic and ecological groups.

Among culture collections of macrofungi in Europe, Culture Collection of Basidiomycetes (CCBAS) of the Institute of Microbiology, Academy of Sciences of the Czech Republic, holds 292 species of the orders Agaricales and Aphyllophorales; of two collections registered in the Russian Federation, the All-Russian Collection of Microorganisms (VKM) maintains 164 species of Agaricales, and the Basidiomycetes Culture Collection of the Komarov Botanical Institute, Russian Academy of Sciences (LE-BIN) - 633 species of Agaricales and Aphyllophorales (Psurtseva, 2008a, b; Psurtseva, Ozerskaya, 2013; Lomberg et al., 2015). These collections preserve the gene pool of a wide taxonomic diversity of mushrooms in culture that can be used in fundamental and applied science, development of bioeconomy and education purposes (Belova et al., 2005; Psurtseva, 2008a, b; Ozerskaya, 2012).

In Ukraine, there are several pure culture collections of macrofungi varied by number of strains and species composition. The IBK Mushroom Culture Collection of the M.G. Kholodny Institute of Botany, National Academy of Sciences of Ukraine is the largest fungal culture collection in Ukraine. Founded in 1966, it holds currently over 1110 strains of 186 species belonging to 88 genera of fungi, Basidiomycota and Ascomycota (Bisko et al., 2016a, b). This unique collection maintains dicaryotic strains of mushrooms from various taxonomic and environmental groups of a wide geographical origin. In 2001, the Cabinet of Ministers of Ukraine defined the IBK Mushroom Culture Collection as the National Heritage of Ukraine (Decree № 1709, adopted on 19 December, 2001). The IBK Mushroom Culture Collection (Curator Dr.Sci. Bisko N.A.) is registered in the WDCM international database (http://www.wfcc. info/ccinfo/index.php/collection/by_id/1152).

Several mushroom culture collections were established at the universities in Ukraine. They are as follows: Collection of the Department of Plant Biology (FCKU) of the Educational and Scientific Centre "Institute of Biology and Medicine", Taras Shevchenko National University of Kyiv (Kyiv), Collections of the Oles Honchar Dnipropetrovsk National University (Dnipro), Tauria State Agrotechnological University (Melitopol), National Forestry and Wood-Technology University of Ukraine (Lviv), National Technical University of Ukraine "Igor Sikorsky Kyiv Polytechnic Institute" (Kyiv), Institute of Breedings and Genetics, 
National Academy of Agricultural Sciences of Ukraine (Odesa), Donetsk National University (Vinnytsia), etc.

The Culture Collection of Fungi (FCKU) of the Department of Plant Biology of the Educational and Scientific Centre "Institute of Biology and Medicine", Taras Shevchenko National University of Kyiv was founded in 2008 and at present holds 55 species of macrofungi of Basidiomycota and Ascomycota (Sukhomlyn, 2010). The FCKU Collection (Curator Prof., Dr.Sci. M.M. Sukhomlyn) is registered in the WDCM database (http://www.wfcc.info/ccinfo/ collection/by_id/1000). One of the objectives of the $F C K U$ Collection is preservation of rare species of macrofungi of Ukraine. It is the only fungal collection in Ukraine containing a pure culture of Laetisaria fuciformis, a potentially dangerous invasive species first recorded in Ukraine in 2006 (Akulov, 2010).

As mentioned above, ex situ method is a prospective approach for conservation of fungi. Its major purpose is to preserve the gene pool of macrofungi in pure culture. Hence, the fungal collections maintain taxonomic diversity of fungi, with an emphasis on rare and endangered species (Psurtseva, 2008a, b; Lomberg et al., 2015; Petrichuk et al., 2014a; Bisko et al., 2016b). In the IBK and FCKU collections, a special attention is also paid to cultures of rare species of fungi, particularly of those listed in the Red Data Book of Ukraine (2009).

For assessing the risk of species extinction, the criteria and categories proposed by the International Union for Conservation of Nature (IUCN) are commonly used; although originally designed for global level, they can be applied for fungal evaluation at the national level (Dahlberg, Mueller, 2011; Hayova, 2014). The existing Ukrainian Red Data Book categories should be consequently harmonized with international ones; the following IUCN categories are recommended to apply in the Red Data Book of Ukraine: Regionally Extinct (RE), Critically Endangered (CR), Endangered (EN), Vulnerable (VU), Near Threatened (NT), Least Concern (LC), and Data Deficient (DD) (Mosyakin et al., 2014).

The IBK and FCKU mushroom culture collections altogether support 124 species evaluated by selected European countries against the IUCN criteria and categories and other nationally accepted categories (ECCF, http://www.eccf.eu/), as well as those listed in the Red Data Book of Ukraine. A list of these species is provided below (Table).

In the IBK and FCKU collections, there are 12 species of mushrooms listed in the Red Data Book of Ukraine (2009). These are Agaricus bresadolanus (A. romagnesii), Clathrus archeri, Fomitopsis officinalis, Grifola frondosa, Gyromitra slonevskii, Hericium coralloides, Leucoagaricus barsii, Morchella steppicola, M. crassipes, Mutinus caninus, Polyporus umbellatus, and Sparassis crispa.

Three species of the genus Sparassis Fr. (S. crispa, $S$. laminosa, and $S$. nemecii) known in Ukraine are held in culture in the IBK and FCKU collections (Berezovska et al., 2012; Mykchaylova, 2017). Only one of them, $S$. crispa, is currently listed in the Red Data Book of Ukraine, although $S$. laminosa and $S$. nemecii are also rarely recorded in our country and need to be protected. Sparassis nemecii is regarded as a species relevant for Red List assessment in some European and Asian countries. Recently, a new locality of this fungus in Ukraine was reported from Hutsulshchyna National Natural Park (Heluta et al., 2016).

There are four strains of Pleurotus nebrodensis (Inzenga) Quel. of various geographical origin in the IBK collection. Until 2014, this species was the only representative of the Fungi Kingdom in the IUCN Red List of Threatened Species (http://www.iucnredlist. org). The occurrence range of this mushroom was estimated as less than 100 square $\mathrm{km}$; in addition, its population was very fragmented and a continuous decrease in localities with mature individuals was observed. Thus, it was evaluated globally in the IUCN Red List as a Critically Endangered (CR) species (Heluta, Hayova, 2014).

There are three strains of Fomitopsis officinalis in the IBK collection. This species is listed in the Red Data Book of Ukraine as Regionally Extinct (RE) in our country. The fungus used to be found in the Carpathian and Western Ukrainian forests; however, for over 50 years it has not been recorded in Ukraine (Mykchaylova, 2016). Fomitopsis officinalis is considered as a species threatened with extinction in North America, 12 countries in Europe and the Asian part of the Russian Federation (Siberia, Far East). Only nine strains of this species are represented in the WFCC database. (http://gcm.wfcc.info/speciesPage.jsp?strain name $=$ Fomitopsis $\% 20$ officinalis). Five of them are stored in the CBS collection (the Netherlands), three in LE-BIN collection (Russian Federation) and one in MUT collection (Italy).

Apart from the species currently listed in the Red Data Book of Ukraine, other rare species of fungi can be regarded as candidates for red-listing. Some of them are continuously maintained in the mushroom 
Table. Species from the IBK and FCKU culture collections listed in the Red Data Book of Ukraine and preliminary European Red List of endangered macrofungi

\begin{tabular}{|c|c|c|c|}
\hline \multirow{2}{*}{ Species } & \multicolumn{2}{|c|}{$\begin{array}{l}\text { Number of } \\
\text { strains }\end{array}$} & \multirow[t]{2}{*}{ IUCN categories or conservation status, countries } \\
\hline & IBK & FCKU & \\
\hline Abortiporus biennis (Bull.) Singer & 1 & - & CR: Estonia; LC: Denmark \\
\hline Agaricus arvensis Schaeff. & 2 & - & LC: Denmark, Latvia, Norway \\
\hline Agaricus bisporus (J.E.Lange) Imbach & 59 & 1 & LC: Denmark, Latvia, Norway \\
\hline Agaricus bitorquis (Quél.) Sacc. & 7 & 1 & LC: Denmark, Latvia, France \\
\hline *Agaricus bresadolanus Bohus (= Agaricus romagnesii Wasser) & 2 & - & DD: Czech Republic; SU: Netherlands \\
\hline Agaricus xanthodermus Genev & 3 & - & VU: Latvia; LC: Norway \\
\hline Agrocybe praecox (Perst.) Fayod & - & 1 & LC: Latvia \\
\hline Auricularia auricula-judae (Bull.) Quél. & 9 & - & LC: Latvia, France \\
\hline Bolbitius vitellinus (Pers.) Fr. (= Bolbitius titubans (Bull.) Fr. & - & 1 & LC: Denmark, Latvia, Norway; DD: Turkey \\
\hline Ceraporia viridans (Berk. \& Broome) Donk & - & 1 & EN: Netherlands; R: Poland \\
\hline Chondrostereum purpureum (Pers.) Pouzar & 2 & 1 & LC: Latvia \\
\hline $\begin{array}{l}\text { Chlorophyllum rachodes (Vittad.) Vellinga } \\
\text { (= Macrolepiota rachodes (Vittad.) Singer) }\end{array}$ & 1 & - & LC: Latvia; R: Russia, Turkey \\
\hline *Clathrus archeri (Berk.) Dring & 1 & - & NT: Romania; R: Bulgaria \\
\hline $\begin{array}{l}\text { Coprinopsis cinerea (Schaeff.) Redhead, Vilgalys \& Moncalvo } \\
\text { (= Coprinus cinereus (Schaeff.) Gray) }\end{array}$ & 2 & - & VU: Netherlands; DD: Latvia \\
\hline Coprinus comatus (O.F. Mull.) Pers. & 13 & 1 & LC: Latvia \\
\hline Coprinus micaceus (Bull.) Fr. & - & 1 & LC: Latvia \\
\hline Cordyceps militaris (L.) Fr. & 5 & - & LC: Norway; R: Poland \\
\hline Cyathus olla (Batsch) Pers. & 2 & - & NT: Norway; LC: Latvia \\
\hline Cyathus striatus (Huds.) Willd. & 1 & 1 & LC: Latvia \\
\hline Cyclocybe aegerita (V. Brig.) Vizzini (= Agrocybe aegerita (V. Brig.) Singer) & 15 & - & R: France, Malta \\
\hline $\begin{array}{l}\text { Cyclocybe cylindracea (DC.) Vizzini \& Angelini } \\
\text { (= Agrocybe cylindracea (DC.) Maire) }\end{array}$ & 1 & - & NT: Slovakia; LC: Poland \\
\hline Fistulina hepatica (Schaeff.) With. & 9 & - & VU: Latvia; LC: Denmark \\
\hline Flammulina velutipes (Curtis) Singer & 42 & 9 & VU: Turkey; LC: Denmark \\
\hline $\begin{array}{l}\text { Fomitiporia robusta (P. Karst.) Fiasson \& Niemelä } \\
\text { (= Phellinus robustus (P. Karst.) Bourdot \& Galzin) }\end{array}$ & 3 & - & EN: Denmark; VU: United Kingdom; NT: Finland \\
\hline $\begin{array}{l}\text { Fomitopsis betulina (Bull.) B.K. Cui, M.L. Han \& Y.C. Dai } \\
\text { (= Piptoporus betulinus (Bull.) Karst.) }\end{array}$ & 26 & 7 & LC: Latvia \\
\hline $\begin{array}{l}\text { *Fomitopsis officinalis (Vill.) Bondartsev \& Singer } \\
\text { (= Laricifomes officinalis (Vill.) Kotl. et Pouzar) }\end{array}$ & 3 & - & $\begin{array}{l}\text { CR: Germany; EN: Poland, Romania, Slovakia; } \\
\text { VU: Switzerland; SU: Netherlands }\end{array}$ \\
\hline Fomitopsis pinicola (Sw.) P.Karst. & 7 & - & LC: Latvia \\
\hline Ganoderma carnosum Pat. & 1 & - & VU: Germany, Poland \\
\hline Ganoderma lucidum (Curtis) P. Karst. & 39 & 1 & VU: Latvia; LC: Denmark \\
\hline Ganoderma resinaceum Boud. & 2 & - & EN: Denmark, Germany \\
\hline Gloeophyllum odoratus (Wulfen) Imazeki & 1 & - & EN: Netherlands; LC: Denmark \\
\hline Gloeophyllum sepiarium (Wulfen) P. Karst. & 2 & - & EN: Netherlands; LC: Latvia \\
\hline *Grifola frondosa (Dicks.) Gray & 29 & 1 & $\begin{array}{l}\text { CR: Estonia; EN: Bulgaria; VU: Finland, Latvia, Poland, } \\
\text { Turkey; NT: Romania, Sweden; DD: Serbia; DC: Norway }\end{array}$ \\
\hline Gyromitra infula (Schaeff.) Quél. & 1 & - & CR: Netherlands; R: Denmark \\
\hline *Gyromitra slonevskii Heluta & 1 & - & R: Ukraine \\
\hline Hericium abietis (Weir ex Hubert) K.A. Harrison & 1 & - & R: Ukraine \\
\hline Hericium alpestre Pers. & 1 & - & EN: Croatia, Germany \\
\hline $\begin{array}{l}\text { Hericium cirrhatum (Pers.) Nikol. } \\
\text { (= Creolophus cirrhatus (Pers.) P. Karst.) }\end{array}$ & 2 & 2 & $\begin{array}{l}\text { VU: Denmark, Germany, Poland; DD: Montenegro, } \\
\text { Serbia; R: Bulgaria }\end{array}$ \\
\hline Hericium clathroides (Pall.) Pers. & 2 & - & DD: Serbia \\
\hline *Hericium coralloides (Fr.) Gray & 3 & 1 & CR: Belgium; EN: Croatia \\
\hline Hericium erinaceus (Bull.) Pers. & 20 & - & CR: Denmark, Norway \\
\hline Heterobasidion annosum (Fr.) Bref. & 1 & 1 & VU: Turkey; LC: Denmark \\
\hline
\end{tabular}

Укр. бот. журн., 2018, 75(4) 


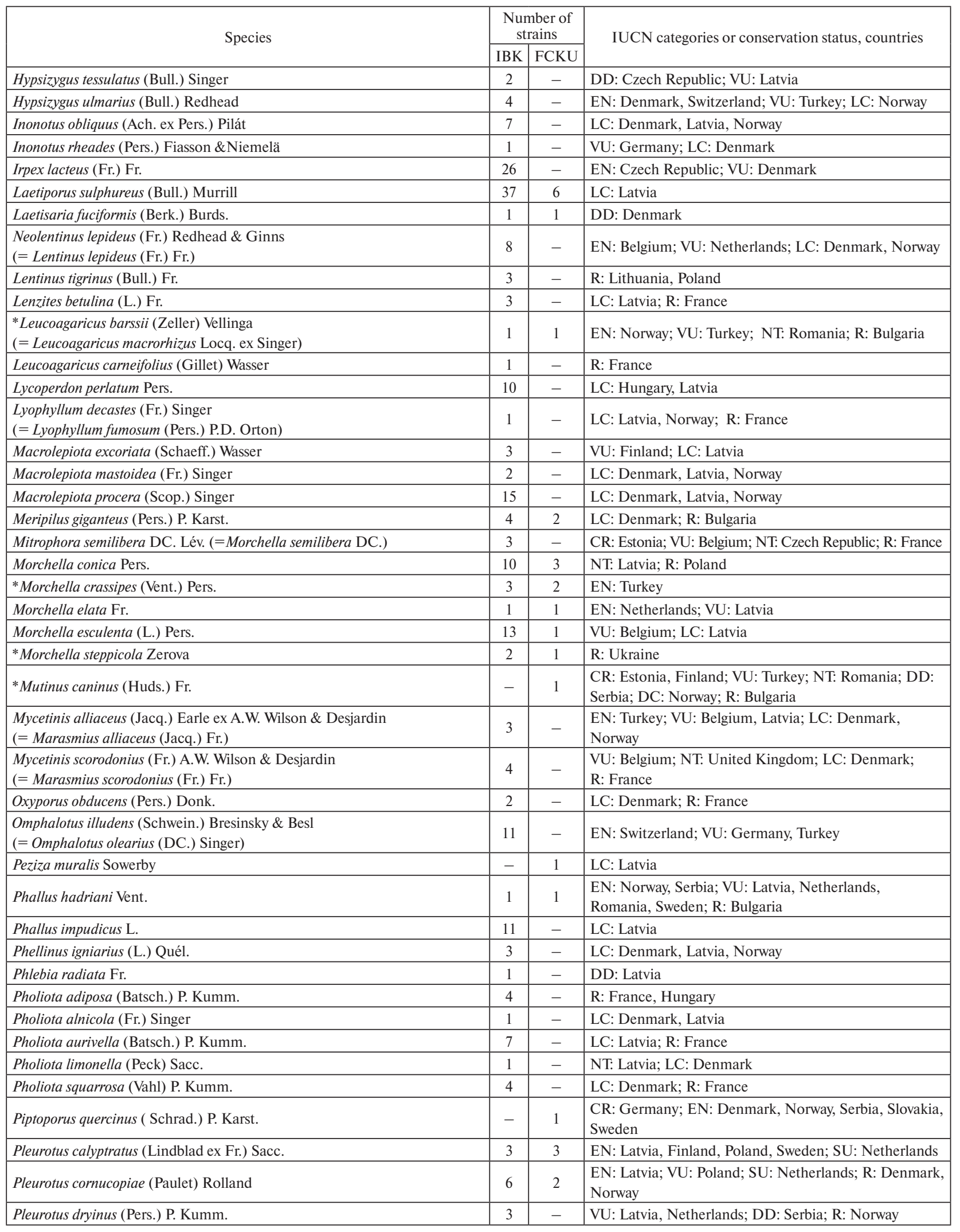




\begin{tabular}{|c|c|c|c|}
\hline \multirow{2}{*}{ Species } & \multicolumn{2}{|c|}{$\begin{array}{c}\text { Number of } \\
\text { strains }\end{array}$} & \multirow{2}{*}{ IUCN categories or conservation status, countries } \\
\hline & IBK & FCKU & \\
\hline Pleurotus eryngii (DC.) Quél. & 36 & 4 & EN: Germany, Slovakia; SU: Netherlands \\
\hline Pleurotus nebrodensis (Inzenga) Quél. & 6 & - & SU: Italy \\
\hline Pleurotus ostreatus (Jacq.) P. Kumm. & 173 & 12 & LC: Latvia \\
\hline Pleurotus pulmonarius (Fr.) Quél. & 17 & - & VU: Poland; LC: Latvia \\
\hline Pleurotus salignus (Pers.) P. Kumm. & 2 & - & VU: Turkey; LC: Latvia \\
\hline Polyporus alveolarius (Bosc) Fr. & - & 1 & EN: Austria \\
\hline Polyporus brumalis (Pers.) Fr. & 1 & - & LC: Latvia; R: Malta \\
\hline Polyporus squamosus (Huds.) Fr. & 3 & - & LC: Latvia \\
\hline *Polyporus umbellatus (Pers.) Fr. & 5 & - & $\begin{array}{l}\text { CR: Estonia; EN: Croatia; VU: Czech Republic, Latvia, } \\
\text { Norway; NT: Denmark, Finland, Great Britain, Sweden }\end{array}$ \\
\hline $\begin{array}{l}\text { Porodaedalea pini (Brot.) Murrill } \\
\text { (= Phellinus pini (Brot.) Bondartsev \& Singer) }\end{array}$ & 1 & - & EN: Netherlands; VU: Denmark, Germany; R: France \\
\hline Postia caesia (Schrad.) P. Karst. & 2 & - & LC: Latvia, Norway; DD: Serbia \\
\hline Psathyrella candolleana (Fr.) Maire & 1 & 1 & LC: Latvia \\
\hline Psathyrella spadiceogrisea (Schaeff.) Maire & - & 1 & DD: Latvia \\
\hline Psilocybe bohemica Šebek & 1 & - & EN: Czech Republic \\
\hline Psilocybe cyanescens Wakef. & 1 & - & EN: Netherlands; R: Denmark \\
\hline Psilocybe semilanceata (Fr.) P. Kumm. & 1 & - & EN: Latvia \\
\hline Ramaria aurea (Schaeff.) Quel. & - & 1 & CR: Germany; EN: Denmark, Norway, Poland, Sweden \\
\hline Rhizina undulata Fr. & 1 & - & EN: Netherlands; LC: Norway \\
\hline $\begin{array}{l}\text { Rhodofomes roseus (Alb. \& Schwein.) Vlasák } \\
\text { (= Fomitopsis rosea (Alb. \& Schwein.) P. Karst.) }\end{array}$ & 1 & - & $\begin{array}{l}\text { EN: Croatia, Germany; } \\
\text { NT: Finland; R: Bulgaria }\end{array}$ \\
\hline Sarcodontia crocea (Schwein.) Kotl. & - & 1 & $\begin{array}{l}\text { RE: Denmark; CR: Finland, Sweden; EN: Netherlands; } \\
\text { VU: Germany; LC: Latvia; R: Estonia, Poland }\end{array}$ \\
\hline *Sparassis crispa (Wulfen) Fr. & 10 & - & $\begin{array}{l}\text { CR: Croatia, Estonia; EN: Turkey; VU: Latvia, } \\
\text { Romania; LC: Czech Republic, Norway; R: Poland }\end{array}$ \\
\hline Sparassis nemecii Pilàt \& Veselý & 1 & - & EN: Czech Republic \\
\hline Sparassis laminosa $\mathrm{Fr}$ & 1 & 1 & RE: Sweden \\
\hline Schizophyllum commune Fr. & 24 & - & VU: Finland, Netherlands; LC: Latvia \\
\hline Spongipellis litschaueri Lohwag & 1 & - & CR: Czech Republic \\
\hline Suillus luteus (L.) Roussel & 1 & - & VU: Netherlands; LC: Latvia \\
\hline $\begin{array}{l}\text { Tolypocladium ophioglossoides (J.F. Gmel.) Quandt, Kepler \& Spatafora (= } \\
\text { Cordyceps ophioglossoides (J.F. Gmel.) Fr.) }\end{array}$ & 3 & - & EN: Netherlands; NT: Romania; R: Poland \\
\hline Trametes gibbosa (Pers.) Fr. & 8 & - & DD: Latvia; DC: Netherlands \\
\hline Trametes hirsuta (Wulfen) Lloyd & 10 & - & VU: Turkey; LC: Latvia \\
\hline Trametes pubescens (Schumach.) Pilát & 2 & - & VU: Denmark; NT: Latvia; DD: Serbia; R: Poland \\
\hline Trametes suaveolens (L.) Fr. & 3 & - & $\begin{array}{l}\text { EN: Finland, Sweden; VU: Denmark, Netherlands, } \\
\text { Norway; NT: Latvia }\end{array}$ \\
\hline Trametes versicolor (L.) Lloyd & 18 & - & NT: Finland; LC: Latvia \\
\hline Trichaptum laricinum (P. Karst.) Ryvarden & 1 & - & NT: Finland, Sweden; DC: Norway \\
\hline Tricholoma ustale (Fr.) P. Kumm. & 1 & - & LC: Denmark \\
\hline Volvariella bombycina (Schaeff.) Singer & 3 & - & $\begin{array}{l}\text { VU: Latvia, Netherlands, Romania, Turkey; NT: } \\
\text { Sweden; R: Denmark, Poland, Serbia }\end{array}$ \\
\hline Volvariella pusilla (Pers.) Singer & 1 & 1 & EN: Latvia; VU: Netherlands \\
\hline Volvariella volvacea (Bull.) Singer & 1 & - & VU: Latvia, Poland \\
\hline $\begin{array}{l}\text { Xanthoporia radiata (Sowerby) Țura, Zmitr., Wasser, Raats \& Nevo (= } \\
\text { Inonotus radiatus (Sowerby) P. Karst.) }\end{array}$ & 1 & - & LC: Denmark, Latvia, Norway; R: France \\
\hline Xylaria polymorpha $($ Pers.) Grev. & 2 & - & CR: Estonia; EN: Finland, Latvia; R: Norway; LR: Turkey \\
\hline
\end{tabular}

* Species listed in the Red Data Book of Ukraine (2009).

IUCN Red List Categories: RE - Regionally Extinct; CR - Critically Endangered; EN - Endangered; VU - Vulnerable; NT Near Threatened; LC - Least Concern; DD - Data Deficient. Other categories: DC - Demanding Conservation; R - Rare; LR - Low-Risk species; SU - Susceptible.

A complete list is available at: http://www.eccf.eu/activities-en.ehtml.

Укр. бот. журн., 2018, 75(4) 
culture collections. For example, the IBK and FCKU collections contain cultures of six species of the genus Hericium (Table). Several species of this genus ( $H$. alpestre, $H$. clathroides, $H$. coralloides, and $H$. erinaceus) were recognized as threatened and therefore are red-listed in many European countries (http://www.eccf.eu/activities-en.ehtml). In our country, all four species are very rarely reported from national nature parks and nature reserves; however, only one of them, $H$. coralloides, is listed in the current edition of the Red Data Book of Ukraine (Petrichuk et al., 2014a, b; Petrichuk, Pasaylyuk, 2015; Fokshei, 2016; Lomberg, 2017).

Culture collections provide an opportunity to reintroduce rare or declining species of fungi into natural habitats. For these purposes, preliminary studies on cultural properties of the species, including growth of vegetative mycelium and development of fruit bodies, are required to enable successful reintroduction. The research on reintroduction techniques has been conducted in Hutsulshchyna National Nature Park in Ukraine (Petrichuk et al., 2014a, b).

Through cooperation with Hutsulshchyna National Nature Park for three years, new strains of the rare and newly recorded species of macrofungi in Ukraine were added to the IBK and FCKU collections (Bisko et al., 2017).

Besides rare species described above, a large number of strains of edible fungi are sustained in the IBK and FCKU collections, such as Agaricus bisporus, Pleurotus ostreatus, Lentinula edodes, Flammulina velutipes, etc. (Lomberg et al., 2015; Bisko et al., 2016). These species are widely cultivated throughout the world. Most of them, except for L. edodes, grow in the wild in Ukraine and apparently do not require additional protection measures. However, they are considered as threatened or rare species in some European countries (Table).

Thus, culture collections of macrofungi, containing numerous strains of mushrooms from various taxonomic and environmental groups of a broad geographical origin, are widely used in fundamental and applied science. The strains held in culture collections are of crucial importance in current taxonomic or phylogenetic studies as well as provide the essential basis for biotechnological potential. The research data on morphological and cultural characteristics of the strains contribute to reliable continuous preservation of the strains under cultural conditions for the purposes of ex-situ conservation, research, and sustainable use of genetic resources.

\section{Acknowledgements}

Authors are sincerely grateful to Dr. Martin Rajtar (Mykoforest, Slovakia) for providing pure cultures received in the $I B K$ mushroom culture collection during 2017-2018.

\section{REFERENCES}

Akulov O.Yu., Dzhagan V.V., Senchylo O.O., Sukhomlyn M.M. Ukr. Bot. J., 2010, 67(6): 898-905. [Акулов О.Ю., Джаган В.В., Сенчило О.О., Сухомлин М.М. Перші знахідки Laetisaria fuciformis (McAlpine) Burds. (Corticiaceае) в Україні. Укр. бот. журн., 2010, 67(6): 898-905].

Belova N.V., Psurtseva N.V., Gachkova E.Yu., Ozerskaya S.M. Mikologiya i Fitopatologiya, 2005, 39(2): 1-10. [Белова Н.В., Псурцева Н.В., Гачкова Е.Ю., Озерская С.М. Сохранение разнообразия базидиомицетов ex situ в специализированной Коллекции культур LE (БИН). Микол. и фитопатол., 2005, 39(2): 1-10].

Berezovska M., Pavlovska M., Karbovska V., Karpenko N., Abduloyeva O., Kondratyuk T., Sukhomlyn M., Kostikov I. Visnyk Kyiv. nats. univ. Ser. Problemy rehulyatsii fiziolohichnykh funktsiy, 2012, 15: 44-47. [Березовська М., Павловська М., Карбовська В., Карпенко Н., Абдулоєва О., Кондратюк Т., Сухомлин М., Костіков I. Значення колекцій у збереженні біорізноманіття у сучасній науковій діяльності. Вісн. Київ. нац. ун-ту. Сер. Проблеми регуляції фізіологічних функцій, 2012, 15: 44-47].

Bisko N.A., Lomberg M.L., Mytropolska N. Yu., Mykchaylova O.B. Kolektsiya kultur shapynkovykh hrybiv (IBK) (IBK Mushroom Culture Collection). Kyiv: Alterpress, 2016a, 120 рр. [Бісько Н.А., Ломберг М.Л., Митропольська Н.Ю., Михайлова О.Б. Колекція культур шапинкових грибів (IBK). Київ: Альтерпрес, 2016а, $120 \mathrm{c.}]$.

Bisko N.A., Lomberg M.L., Mykchaylova O.B., Mitropolska N.Yu., Al-Maali G.A. In: Rare plants and fungi of Ukraine and adjacent areas: implementing conservation strategies: mat. of the $4^{r d}$ Inter. conf. (Ex situ conservation of rare species of macromycetes in the IBK collection of mushrooms). Abstracts. Kyiv: Palyvoda, 2016b, pp. 174177. [Бісько Н.А., Ломберг М.Л., Михайлова О.Б., Митропольська Н.Ю., Аль-Маалі Г.А. Збереження рідкісних видів макроміцетів ex situ в колекції культур шапинкових грибів IBК. У зб.: Рідкісні рослини $i$ гриби Украӥни та прилеглих територій: реалізація природоохоронних стратегій:мат. IV Міжннар. наук. конф. (м. Київ, 16-20 травня 2016 р.). Київ: Паливода, 2016b, c. 174-177].

Bisko N.A., Lomberg M.L., Mytropolska N.Yu., Al-Maali G.A., Mykchaylova O.B. In: Pryrodookhoronni, istoryko-kulturni ta ekosvitni aspekty zbalansovanoho rozvytku Ukrainskykh Karpat: mat. mizhnar. nauk.prakt. konf., prysvyach. 15-y richnytsi NPP Hutsulshchyna. Kosiv: PP Pavluyk, 2017, pp. 209-214. [Бісько H.A., Ломберг М.Л., Митропольська Н.Ю., Аль-Маалі Г.А., Михайлова О.Б. Збереження у колекції культур шапинкових грибів (IBK) рідкісних та зникаючих видів макроміцетів, виділених на території 
НПП "Гуцульщина". У зб.: Природоохоронні, icmoрико-культурні та екоосвітні аспекти збалансованого розвитку Українських Карпат: мат. міжнар. наук.-практ. конф., присвяч. 15-й річниці НПП "Гуцульщина" (м. Косів, Івано-Франківська обл., 8-9 червня 2017 р.). Косів: ПП Павлюк М.Д., 2017, с. 209-214].

Dahlberg A., Mueller G.M. Applying IUCN red-listing criteria for assessing and reporting on the conservation status of fungal species. Fungal Ecology, 2011, 4(2): 147-162.

Dahlberg A., Genney D.R., Heilmann-Clausen J. Developing a comprehensive strategy for fungal conservation in Europe: current status and future needs. Fungal Ecology, 2010, 3(2): 50-64.

Fokshei S.I. In: Ekolohichni, sotsialno-ekonomichni ta istoryko-kulturni aspekty rozvytku terytoriy maramoroshchyny: mat. mizhnar. nauk. -prakt. konf. Rakhiv: FOP Petryshyn, 2016, pp. 305-310. [Фокшей C.I. Регіонально рідкісні таксони мікобіоти НПП "Гуцульщини". У зб.: Екологічні, соціально-економічні та історико-культурні аспекти розвитку прикордонних територій мараморощини: мат. міжнар. наук.-практ. конф. (Рахів, 2-4 вересня 2016 р.). Рахів: ФОП Петришин, 2016, c. $305-310]$.

Hayova V.P. In: Roslynnyi svit u Chervoniy knyzi Ukrainy: vprovadzhennya hlobalnoi stratehii zberedennya roslyn: mat. III Mizhnar. nauk. konf. (The IUCN Red List Categori and Criteria: How they can be applied for assessing the conservation status of fungal species). Lviv: Prostir-M, 2014, pp. 35-36. [Гайова В.П. Категорії та критерії МСОП i особливості їх застосування для оцінки природоохоронного статусу видів грибів. У зб.: Рослинний світ y Червоній книзі України: впровадження глобальної стратегії збереження рослин: мат. III Міжнар. наук. конф. (Львів, 4-7 червня 2014 р.). Львів: Простір-М, 2014, c. 35-36].

Heluta V.P., Hayova V.P. In: Roslynnyi svit u Chervoniy knyzi Ukrainy: vprovadzhennya hlobalnoi stratehii zberedennya roslyn: mat. III Mizhnar. nauk. konf. Lviv: ProstirM, 2014, pp. 181-182. [Гелюта В.П., Гайова В.П. Перша знахідка в Україні рідкісного гриба Pleurotus nebrodensis (Agaricales, Basidiomycota). У зб.: Рослинний світ у Червоній книзі України: впровадження глобальної стратегії збереження рослин: мат. III Міжнар. наук. конф. (Львів, 4-7 червня 2014 р.). Львів: Простір-М, 2014, с. 181-182].

Heluta V.P., Fokshei S.I., Derzhypilskyi L.M. In: Rare plants and fungi of Ukraine and adjacent areas: implementing conservation strategies. Abstracts of the IV Inter. conf. Kyiv: Palyvoda, 2016, pp. 182-184. [Гелюта В.П., Фокшей С.I., Держипільський Л.М. Перші знахідки в Україні рідкісного гриба Sparassis nemecii (Sparassidaceae). У зб.: Рідкісні рослини і гриби України та прилеглих територій: реалізація природоохоронних стратегій: мат. IV Міжнар. наук. конф. (Київ, 16-20 травня, 2016 р.). Київ: Паливода, 2016, с. 182-184].

Lomberg M.L. In: Pryrodookhoronni, istoryko-kulturni ta ekosvitni aspekty zbalansovanoho rozvytku Ukrainskykh Karpat: mat. mizhnar. nauk.-prakt. konf., prysvyach. 15-y richnytsi NPP Hutsulshchyna. Kosiv: PP Pavlyuk, 2017, pp. 237-243. [Ломберг М.Л. Морфолого-культураль- ні властивості рідкісних видів грибів Hericium coralloides та Hericium alpestre (Hericiaceae) з Покутських Карпат. У зб.: Природоохоронні, історико-культурні та екоосвітні аспекти збалансованого розвитку Українських Kарпат: мат. міжнар. наук.-практ. конф., присвяч. 15-й річниці НПП "Гуиульщина" (м. Косів, Івано-Франківська обл., 8-9 червня 2017 р.). Косів: ПП Павлюк, 2017, с. 237-243].

Lomberg M.L., Mykchaylova O.B., Bisko N.A. Mushroom culture collection (IBK) as a subject of national heritage of Ukraine. Ukr. Bot. J., 2015, 72(1): 22-28. http:// dx.doi.org/10.15407/ukrbotj72.01.022

Mosyakin S.L., Korotchenko I.A., Kagalo A.A., Heluta V.P., Hayova V.P. In: Roslynnyi svit u Chervoniy knyzi Ukrainy: vprovadzhennya hlobalnoi stratehii zberedennya roslyn: mat. III Mizhnar. nauk. konf. Lviv: Prostir-M, 2014, pp. 51-56. [Мосякін С.Л., Коротченко І.А., Кагало О.О., Гелюта В.П., Гайова В.П. Зміна категорій видів рослин та грибів, що включені до Червоної книги України: проблеми, пропозиції, перспективи. У зб.: Рослинний світ у "Червоній книзі України": впровадження глобальної стратегії збереження рослин: мат. міжнар. конф. (Львів, 4-7 червня 2014 р.). Львів: Простір-М, 2014, с. 51-56].

Mykchaylova O.B. In: Rare plants and fungi of Ukraine and adjacent areas: implementing conservation strategies. Abstracts of the IV Int. conf. Kyiv: Palyvoda, 2016, pp. 190192. [Михайлова О.Б. Морфолого-культуральні властивості лікарського гриба Fomitopsis officinalis (Fomitopsidaceae, Polyporales), занесеного до Червоної книги України. У зб.: Рідкісні рослини і гриби України та прилеглих територій: реалізація природоохоронних стратегій: мат. IV Міжнар. наук. конф. (Київ, 16-20 травня 2016 р.). Київ: Паливода, 2016, с. 190-192].

Mykchaylova O.B. In: Pryrodookhoronni, istoryko-kulturni ta ekosvitni aspekty zbalansovanoho rozvytku Ukrainskykh Karpat: mat. mizhnar. nauk.-prakt. konf., prysvyach. 15-y richnytsi NPP Hutsulshchyna. Kosiv: PP Pavlyuk, 2017, pp. 243-245. [Михайлова О.Б. Культурально-морфологічні властивості рідкісного гриба Sparassis nemecii (Sparassidaceae, Polyporales). У зб.: Природоохоронні, історико-культурні та екоосвітні аспекти збалансованого розвитку Українських Kарпат: мат. міжнар. наук.-практ. конф., присвяч. 15-й річниці НПП "Гуцульщина" (м. Косів, Івано-Франківська обл., 8-9 червня 2017 р.). Косів: ПП Павлюк, 2017, с. 243-245].

Ozerskaya S. M. Hriby v kollektsyyakh kultur: fundamentalnye $i$ prikladnye aspekty: Cand. Sci. Diss. Abstract. Moscow, 2012, 51 pp. [Озерская C.M. Грибы в коллекциях культур: фундаментальне и прикладные аспекmы: автореф. дис. ... Д-ра биол. наук: спец. 03.02.12 "Микология". М., 2012, 51 с.].

Petrichuk Yu.V., Pasaylyuk M.V., Sukhomlyn M.M. In: Roslynnyi svit u Chervoniy knyzi Ukrainy: vprovadzhennya hlobalnoi stratehii zberedennya roslyn: mat. III Mizhnar. nauk. konf. Lviv: Prostir-M, 2014a, pp. 232-234. [Петричук Ю.В., Пасайлюк М.В., Сухомлин М.Н. Збереження рідкісних видів грибів. Технологія re situ. У зб.: Рослинний світ у "Червоній книзі України": впровадження глобальної стратегії збереження 
рослин:мат. міжнар. конф. (Львів, 4-7червня 2014р.). Львів: Простір-М, 2014a, с. 232-234].

Petrichuk Yu., Pasaylyuk M., Sukhomlin M. Pryroda Zakhidnoho Polissya ta prylehlykh terytoriy, 2014b, 11: 162-166. [Петричук Ю.В., Пасайлюк М.В., Сухомлин М.М. Гриби Червоної книги України в культурі. Закономірності росту Hericium coralloides. Природа Західного Полісся та прилеглих територій, 2014b, 11: 162-166].

Petrichuk Yu., Pasaylyuk M. New records of the fungi listed in the Red Data Book of Ukraine from the Pokutski Carpathians. Ukr. Bot. J., 2015, 72(4): 381-384. http:// dx.doi.org/10.15407/ukrbotj72.04.381

Psurtseva N.V. In: Materialy II s'ezda mikologov Rossii. Moscow: Nats. acad. mycologii, 2008a, issue 2, pp. 111112. [Псурцева Н.B. Коллекция культур LE (БИН) как основа для сохранения ex situ разнообразия базидиальных макромицетов России. В сб.: Материлы II Съезда микологов России. М.: Нац. акад. микологии, 2008а, вып. 2, с. 111-112.

Psurtseva N.V. In: Materialy yubileynoy konferentsii, posvyashchennoy 110-letiyu M.V. Gorlenko. Moscow: Vostok-Zapad, 2008b, pp. 174-181. [Псурцева Н.В. Культуральная характеристика как основа верификации макромицетов при сохранении ex situ. В сб.: Материаль юбилейной конференции, посвященной 110-летию М.В. Горленко. М.: Восток-Запад, 2008b, c. 174-181].
Psurtseva N., Ozerskaya S. Culture collections: germplasm resources for medicinal mushroom science and production. In: $7^{\text {th }}$ Inter. Med. Mushr. Conf. (IMMC7) (Beijing, 26-29 August 2013). Beijing, China, 2013, pp. 22-24.

Red Data Book of Ukraine. Plant Kingdom. Ed. Ya.P. Didukh. Kyiv: Hlobalkonsaltynh, 2009, 912 pp. [Червона книга Украйни. Рослинний світ. Ред. Я.П. Дідух. Київ: Глобалконсалтинг, 2009, 912 с.].

Sukhomlyn M.M. Pryroda Zakhidnoho Polissya ta prylehlykh terytoriy, 2010, 7: 102-107. [Сухомлин М.М. Колекція культур грибів-макроміцетів як основа стратегії збереження генофонду базидіальних й аскоміцетних грибів. Природа Західного Полісся та прилеглих територій, 2010, 7: 102-107].

Recommended for publication by V.P. Hayova
Submitted 26.06.2018 
Бісько Н.А. ${ }^{1}$, Сухомлин М.М. ${ }^{2}$, Михайлова О.Б. ${ }^{1}$, Ломберг М.Л. ${ }^{1}$, Цвид Н.В. ${ }^{2}$, Петричук Ю.В. ${ }^{3}$, Аль-Маалі Г.А., Митропольська Н.Ю. Збереження еx situ рідкісних і зникаючих видів макроміцетів у колекціях культур грибів в Україні. Укр. бот. журн., 2018, 75(4): 338-347.

${ }^{1}$ Інститут ботаніки ім. М.Г. Холодного НАН України вул. Терещенківська, 2, Київ 01004, Україна

2 Учбово-науковий центр "Інститут біології та медицини" Київського національного університету імені Тараса Шевченка просп. Глушкова, 2, Київ 03127, Україна

${ }^{3}$ Національний природний парк "Гуцульщина" вул. Дружби, 84, Косів 78600, Івано-Франківська обл., Україна

Зменшення біорізноманіття, деградація екосистем та інші глобальні проблеми окреслюють невідкладні завдання охорони природи. Гриби як важливий компонент біорізноманіття мають підлягати охороні так само, як й інші живі організми. У статті викладено дві основні стратегії охорони та розглянуто останні досягнення в охороні грибів як in situ, так і ex situ. Висвітлено провідну роль колекцій грибних культур для збереження грибів ex situ. Збереження видового різноманіття та генетичних ресурсів у колекціях культури є основою для розвитку біотехнології. Наведено найбільші колекції грибів, які зареєстровано у Всесвітньому центрі даних щодо мікроорганізмів (WDCM) - унікальній глобальній мережі для збереження грибного та мікробного різноманіття ex situ. Серед існуючих колекцій культур грибів в Україні охарактеризовано колекції грибів IBK та FCKU. Наводиться список видів, які підтримуються в колекціях IBK i FCKU і входять, у відповідності з критеріями й категоріями МСОП, до Європейського Червоного Списку грибів, доступного на веб-сторінці Європейської ради з охорони грибів (ЕCCF). Зазначається, що особливу увагу в колекціях IBK та FCKU приділено вивченню культур рідкісних видів грибів, особливо тих, що внесені до Червоної книги України, а також можливості їхньої реінтродукції у природні оселища. Наводяться деякі приклади інших рідкісних видів грибів з цих колекцій, які є потенційними кандидатами на внесення до Червоної книги України.

Ключові слова: охорона, колекція культур, гриби, МСОП, Червоний список
Бисько Н.А. ${ }^{1}$, Сухомлин М.Н. ${ }^{2}$, Михайлова О.Б. ${ }^{1}$, Ломберг М.Л. ${ }^{1}$, Цвыд Н.В. ${ }^{2}$, Петричук Ю.В. ${ }^{3}$, Аль-Маали Г.А., Митропольская Н.Ю. Сохранение ex situ редких и исчезающих видов макромицетов в коллекциях культур грибов в Украине. Укр. бот. журн., 2018, 75(4): 338-347.

${ }^{1}$ Институт ботаники им. Н.Г. Холодного НАН Украины ул. Терещенковская, 2, Киев 01004, Украина

2 Учебно-научный центр "Институт биологии и медицины" Киевского национального университета имени Тараса Шевченко просп. Глушкова, 2, Киев 03127, Украина

${ }^{3}$ Национальный природный парк "Гуцульщина" ул. Дружбы, 84, Косив 78600, Ивано-Франковская обл., Украина

Сокращение биоразнообразия, деградация экосистем и другие глобальные проблемы определяют неотложные задачи в области охраны природы. Грибы как важный компонент биоразнообразия подлежат охране в той же мере, что и другие живые организмы. В статье изложены две основные стратегии охраны природы, а также рассмотрены последние достижения в охране грибов как in situ, так и ex situ. Подчеркивается ключевая роль коллекций культур для охраны грибов ex situ. Сохранение видового разнообразия и генетических ресурсов в коллекциях культур является основой для развития биотехнологии. Упоминаются крупнейшие коллекции грибов, зарегистрированные во Всемирном центре данных о микроорганизмах (WDCM) - уникальной глобальной сети для охраны ex situ грибного и микробного разнообразия. Из числа современных коллекций культур грибов в Украине охарактеризованы коллекции IBK и FCKU. Приводится список видов, поддерживаемых в коллекциях IBK и FCKU, которые входят, в соответствии с критериями и категориями МСОП, в Европейский Красный Список грибов, доступный на веб-сайте Европейского совета по охране грибов (ECCF). Обсуждается важное значение культур редких видов грибов в коллекциях IBK и FCKU, особенно тех, которые внесены в Красную книгу Украины, а также возможность их реинтродукции в естественные местоообитания. Приводятся некоторые примеры других редких видов грибов из этих коллекций, потенциальных кандидатов для внесения в Красную книгу Украины.

Ключевые слова: охрана, коллекции культур, грибы, МСОП, Красный список 